\title{
High-temperature oxidation and its kinetics study of Ti-6Al-4V alloys in air
}

\begin{abstract}
Tomoshi TAKAHASHI*, Yoritoshi MINAMINO** Hideyuki HIRAZAWA* and Tadashi OUCHI*

The high-temperature oxidation behavior of Ti-6mass $\% \mathrm{Al}-4$ mass $\% \mathrm{~V}$ alloys have been investigated in temperature ranges of 773 to $973 \mathrm{~K}$, and 1123 to $1273 \mathrm{~K}$, in air. A kinetic study of the oxidation has been also carried out in Ti-6 mass $\% \mathrm{Al}-4$ mass $\% \mathrm{~V}$ alloy. The oxidation products have been examined by X-ray diffraction (XRD), electron probe microanalysis (EPMA) and X-ray photoelectron spectroscopy (XPS). The banded $\mathrm{Al}_{2} \mathrm{O}_{3}$ layer is probably formed in the oxides of the Ti-6 mass $\% \mathrm{Al}-4$ mass $\% \mathrm{~V}$ alloy by means of EPMA, although the rutile $\mathrm{TiO}_{2}$ is mostly detected by means of XRD in the oxides of surface layer in the alloy at $1273 \mathrm{~K}$. Furthermore, the $\mathrm{TiO}_{2}$ and $\mathrm{Al}_{2} \mathrm{O}_{3}$ are observed by XPS in surface of the above alloy at $1123 \mathrm{~K}$ for $3.6 \mathrm{ks}$, but the $\mathrm{V}_{2} \mathrm{O}_{5}$ is not observed. It is found that the apparent activation energy for the isothermal oxidation in the Ti-6 mass $\% \mathrm{Al}-4$ mass $\% \mathrm{~V}$ alloys is $Q_{i}=223 \mathrm{~kJ} / \mathrm{mol}$, and the activation energy for the non-isothermal oxidation (TG experiment) at a constant heating rate is $Q_{a}=209 \mathrm{~kJ} / \mathrm{mol}$ in the present alloys.
\end{abstract}

(Received December 10, 2015 Accepted February 28, 2016)

Keywords: high-temperature oxidation, Ti-6Al-4V alloys, kinetic study

\section{1. 緒言}

筆者らは前報 ${ }^{1)}$ において $\mathrm{Ti}-\mathrm{Al}$ および $\mathrm{Ti}-\mathrm{V}$ 合金の高温酸 化に関する研究を報告し, Ti-V 合金の酸化物の成長速度は, $\mathrm{Ti}-\mathrm{Al}$ 合金のそれに比較してかなり大きいことを示した。ま た, $\mathrm{Ti}-\mathrm{V}$ 合金の高温酸化中においては, $\mathrm{TiO}_{2}$ の成長を促進 させるVOの生成の可能性を示唆した。

Ti-6Al-4V 合金はすぐれた強度と延性の組み合わせを有 し，中高温での機械的性質にも優れていることから航空機用 エンジン部材として使用されている ${ }^{2)}$ ○)。このため, これ まで Ti-6Al-4V 合金についての材料組織ならびに材料強度に 関する研究は多く行われている ${ }^{6) \sim 8)}$ 。しかし, Ti-Al-V合金 において，Ti-V 合金に $\mathrm{Al}$ を添加したことによる酸化挙動の 変化, すなわち, $\mathrm{V}$ の選択的酸化や $\mathrm{V}$ 酸化物の生成挙動につ いては明らかでない。さらに前報 ${ }^{1)}$ において Ti-6\%Al合金お よび $\mathrm{Ti}-4 \% \mathrm{~V}$ 合金における見掛けの酸化の活性化エネルギー が報告されているが，Ti-6Al-4V 合金のその值は報告されて いない。

このように, 本合金の高温酸化とその速度的研究 ${ }^{5)}$ はま だ少ないので，それらの研究結果を報告する。

\section{2. 実験方法}

純度 99.7 mass\%の Ti（以下 mass\%は \%と略記）， 99.99\%Al および $99.9 \% \mathrm{~V}$ の純金属試料を用いて，Ti-6\%Al-4\%Vの組成 で配合した全量 $30 \mathrm{~g}$ からアルゴンアーク溶解炉を用いてボ夕 ンインゴットを作製した。このボタンインゴットから差動 型示査熱天秤（TG）測定用として $2.5 \mathrm{~mm} \times 2.5 \mathrm{~m} \times 2 \mathrm{~mm}$ の試 片, 電気炉での等温酸化実験用として $7 \mathrm{~mm} \times 5 \mathrm{~mm} \times 3 \mathrm{~mm}$ の 試片に切り出し, エメリー紙で\#4/0まで研磨した後, アセ トン脱脂して酸化実験に供した。高温酸化実験はすべて大気 中で行い, 中高温域の 773 973K $(86.4 \sim 2592 \mathrm{ks})$ と高温域 の $1123 \sim 1273 \mathrm{~K} （ 3.6 \sim 172.8 \mathrm{ks})$ での等温酸化実験および TG による室温から $1273 \mathrm{~K}$ までの等速酸化実験（加熱速度：2 $30 \mathrm{~K} / \mathrm{min}$ ) を行った。空冷後, 各種合金の酸化増量, すなわ ち単位面積あたりの酸化重量を測定した。酸化表面は走査型 電子顕微鏡 $(\mathrm{SEM})$ により観察し, 一部の酸化試料につい てはX線回折 (XRD) 実験および光電子分光法 (XPS) 測定 を行った。試料表面および断面の観察にはX線マイクロアナ ライザ（EPMA）を用いた。

\footnotetext{
*新居浜工業高等専門学校環境材料工学科（†792-8580 愛媛県新居浜市八雲町 7-1） Department of Environmental Materials Engineering, Institute of Niihama National College of Technology (7-1 Yagumo-cho, Niihama-shi, Ehime 792-8580) E-mail: ttaka@mat.niihama-nct.ac.jp

***大阪大学大学院工学研究科知能・機能創成工学専攻 (吹田市) Department of Adaptive Machine systems, Graduate School of Engineering, Osaka University (Suita-shi, Osaka)
} 


\section{3. 結果および考察}

3. $1 \mathrm{Ti}-6 \mathrm{Al}-4 \mathrm{~V}$ 合金の高温酸化の組織学的結果と考察

3.1.1 等温酸化

Fig. 1 は中高温域の 773 973 Kでの本合金の酸化増量と 時間 $(\sqrt{t})$ との関倸である。Fig. 2(a)，（b）抢よび (c)

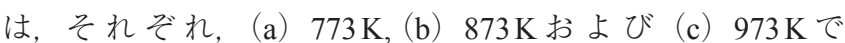
$2592 \mathrm{ks}$ （30日）の大気中暴露試験での酸化表面を SEMで観 察したものである。Fig. 1より明らかであるように，酸化 増量は時間の平方根と共にほぼ直線的に増加しているが,

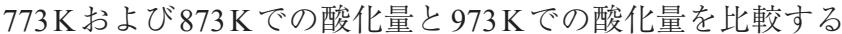
と, $973 \mathrm{~K}$ の酸化量は約 8 倍程度大きい。Fig. 2 に示すように, 各温度での $2592 \mathrm{ks}$ （30日）表面の酸化物の形状は，773K お よび $873 \mathrm{~K}$ の表面形状は大きな塊状のものと針状の酸化物に

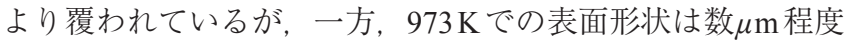
の粒径の酸化物, もしくは柱状の酸化物に均一に覆われてい る。これは前報 ${ }^{1)}$ で報告したように, $\mathrm{V}_{2} \mathrm{O}_{5}$ の融点が $943 \mathrm{~K}$ で あり，この $\mathrm{V}_{2} \mathrm{O}_{5}$ の生成・溶融が高温酸化現象に大きな影響 を与え密接に関係していると考えられる。

Fig. 3 には高温領域の 1273 K, 172.8ksでの等温酸化後, Ti-6Al-4V 合金から剥離・採取した酸化皮膜のX線回折図形 を示す。なお，Fig. 3 には比較のため前報1)で報告した純 Ti, Ti-6Al 抢よびTi-4V 合金の表面酸化皮膜の XRD 結果も示し

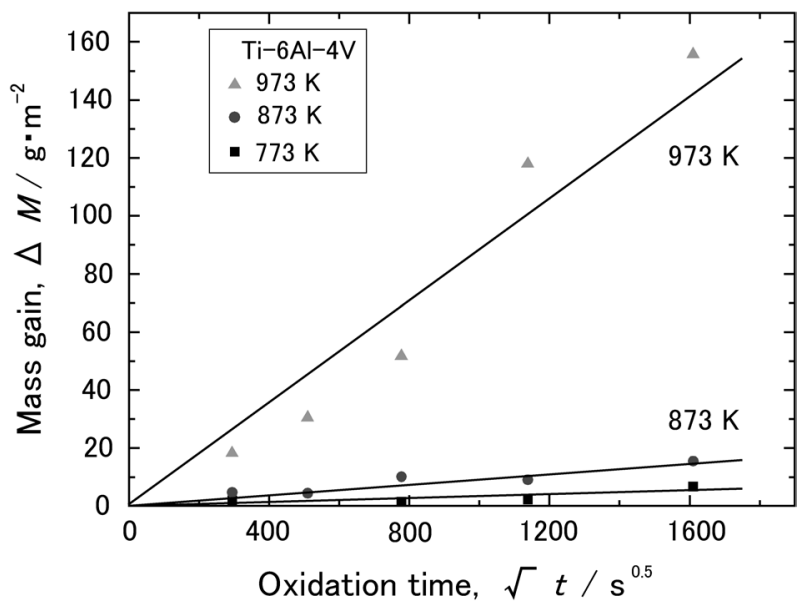

Fig. 1 Relation between mass gain and square root of oxidation time in $\mathrm{Ti}-6 \% \mathrm{Al}-4 \% \mathrm{~V}$ alloys at temperatures from 773 to $973 \mathrm{~K}$.
た。Ti-6Al-4V 合金において，ルチル型 $\mathrm{TiO}_{2}$ と $\alpha-\mathrm{Al}_{2} \mathrm{O}$ ピーク が観察されたが，低圧酸素下において702〜1087Kで検出さ れた $\mathrm{V}$ の酸化物 ${ }^{9)}$ ，すなわち $\mathrm{VO}_{2}, \mathrm{~V}_{2} \mathrm{O}_{5}, \mathrm{~V}_{6} \mathrm{O}_{13}$ および $\mathrm{V}_{2} \mathrm{O}_{3}$ は 本合金においても検出されなかった。これらのことから，前 報 ${ }^{1)}$ の Ti-V 合金と同様， Ti-6Al-4V 合金においても $\mathrm{V}_{2} \mathrm{O}_{5}$ の 蒸発・消失が示唆される。なお, Fig. 3 中の Ti-6Al合金 ${ }^{1)}$ と 同様，Ti-6Al-4V 合金においても剥離・採取していない酸化 表面のみの XRD 結果では $\alpha-\mathrm{Al}_{2} \mathrm{O}$ ピークは検出されなかった。

Fig. 4 は大気中で $1123 \mathrm{~K}(3.6 \mathrm{ks})$, 等温酸化実験したTi6Al-4V 合金の表面酸化皮膜のEPMA観察結果であり，Fig. 5 は $1273 \mathrm{~K}(172.8 \mathrm{ks})$ での本合金の酸化皮膜断面の EPMA 観 察結果である。Fig. 4 と Fig. 5 において, それぞれ, (a) 2 次 電子像（SEM像），（b）組成像（CP像），（c）AlK $\alpha$ 線像，（d） $\mathrm{TiK} \alpha$ 線像, (e) $\mathrm{VK} \alpha$ 線像および（f） $\mathrm{O} \alpha$ 線像である。Fig. 4(c)〜 (f) のX線像から判断して, Fig. 4(a) の SEM像の粒 状あるいは針状, ウィスカ状の酸化物はルチル型 $\mathrm{TiO}_{2}, 2$ 2

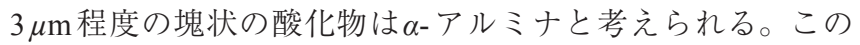
ように本合金の $1123 \mathrm{~K}$ での比較的短時間（3.6 ks）酸化では, その表面酸化皮膜に $\alpha-\mathrm{Al}_{2} \mathrm{O}_{3}$ も存在する。しかし, Fig. 5 は, Fig. 4 に比べて高温 $(1273 \mathrm{~K})$ でしかも長時間（172.8ks）酸 化であり，Fig. 5 (c)〜（f）の Ti, Al, V および $\mathrm{OK} \alpha の \mathrm{X}$ 線像か ら判断されるように，本系合金の断面・酸化物層は，大部 分，ルチル型 $\mathrm{TiO}_{2}$ 相であり， $\alpha-\mathrm{Al}_{2} \mathrm{O}_{3}$ 相は，酸化表面ではな く酸化物相内部に帯状に存在する。また, Fig. $5(\mathrm{e})$ において, 酸化物層と Ti-6Al-4V 合金との境界で $\mathrm{V}$ 元素濃度の比較的多

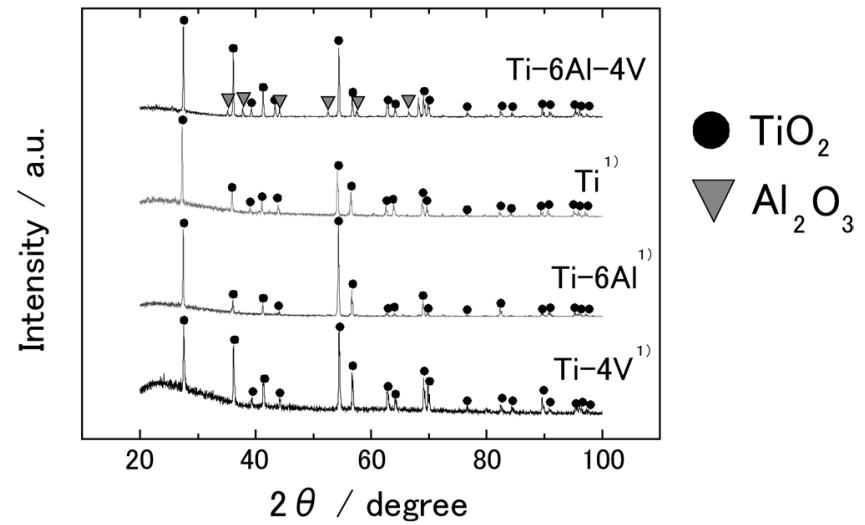

Fig. 3 X-ray diffraction patterns obtained from surfaces of scales in $99.7 \% \mathrm{Ti}^{1)}, \mathrm{Ti}-6 \% \mathrm{Al}^{1)}, \mathrm{Ti}-4 \% \mathrm{~V}^{1)}$ and $\mathrm{Ti}-6 \mathrm{Al}-4 \mathrm{~V}$ alloys oxidized at $1273 \mathrm{~K}$ for $172.8 \mathrm{ks}$. (a)

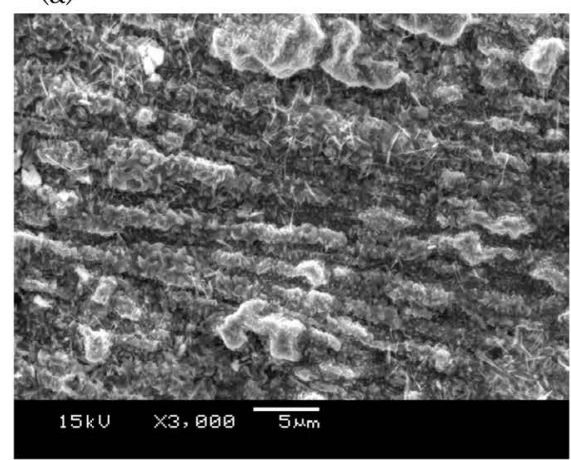

(b)

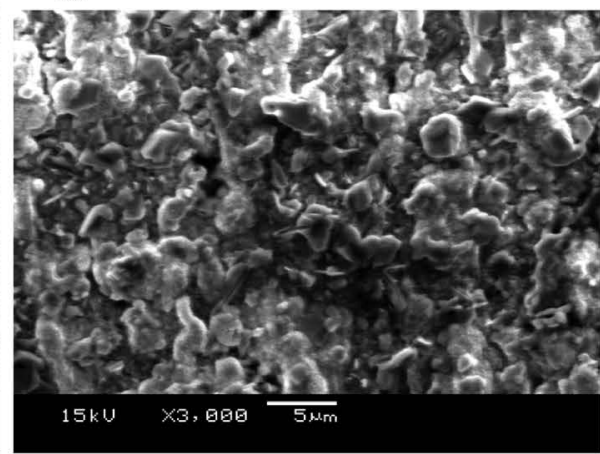

(c)

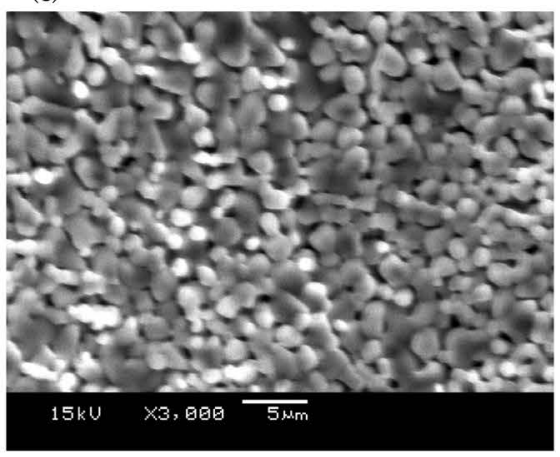

Fig. 2 SEM photographs showing surface morphologies of the Ti-6Al-4V alloys (a) at $773 \mathrm{~K}$ for $30 \mathrm{~d}$, (b) at $873 \mathrm{~K}$ for $30 \mathrm{~d}$ and (c) at $973 \mathrm{~K}$ for $30 \mathrm{~d}$. 
い領域が存在している。

Fig. $6(\mathrm{a}) \sim(\mathrm{c})$ は, Fig. 4 と同条件の中高温（1123K）で 短時間 $(3.6 \mathrm{ks})$ ，等温酸化した本合金の表面酸化皮膜を $\mathrm{X}$ 線光電子分光法 (XPS) により測定した強度と結合エネル ギーとの関係である。ここで，記号の Ar1 は 1 分間 Arイオ ンエッチングにより表面をクリーニングしたこと, Ar2 は さらに1分間表面をクリーニングしたこと，Ar3〜Ar8はそ れぞれ 5 分ごと総時間 30 分までエッチングを行った後の測 定を意味する。Fig. 6 に示すように，最表層の酸化物にお いて（a） $\mathrm{TiO}_{2}$ ，（b） $\mathrm{Al}_{2} \mathrm{O}_{3}$ が検出されている。この結果は Fig. 4のEPMA結果と矛盾しない。なお，Fig. 6(a) におい

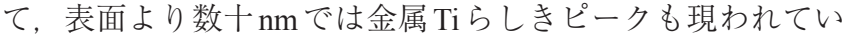
る。前報 ${ }^{1)}$ の Fig. 4 において示したように，Ti-6Al-4V 合金 は $973 \mathrm{~K}$ 付近から酸化が始まっており，エリンガム図 ${ }^{10)} に よ$

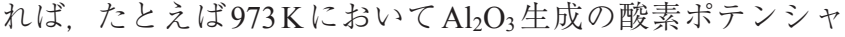
ル $\left(P_{\mathrm{O}_{2}}=8.5 \times 10^{-50} \mathrm{~atm}\right)$ は $\mathrm{TiO}_{2}$ のそれ $\left(P_{\mathrm{O}_{2}}=5.9 \times 10^{-42} \mathrm{~atm}\right)$ に 比べてかなり小であるので, $973 \mathrm{~K}$ 付近での本合金の中高温 酸化において，平衡論的にはまず $\mathrm{Al}_{2} \mathrm{O}_{3}$ が形成することがわ かる。このように，中高温・短時間酸化では，酸化表面近 傍に $\mathrm{Al}_{2} \mathrm{O}_{3}$ が存在することになる。Fig. 6 (c) において明瞭な
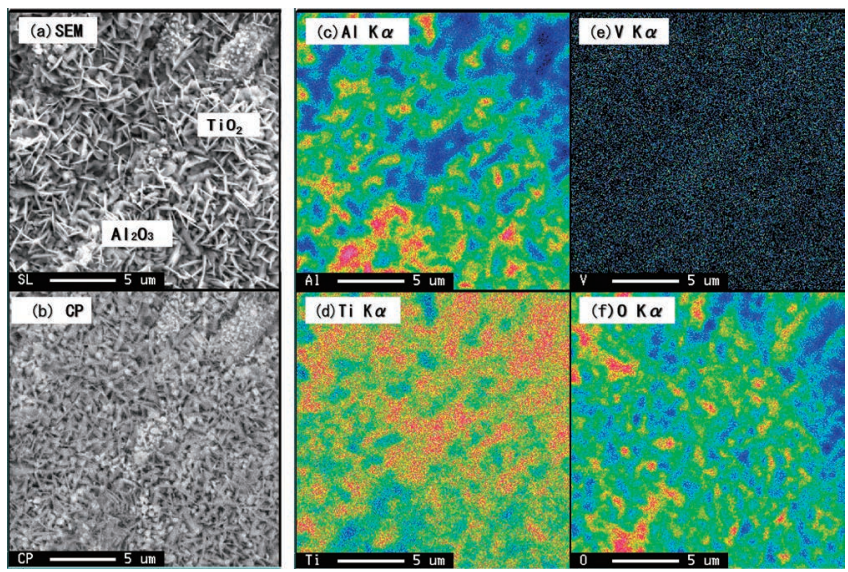

Fig. 4 EPMA photographs of the oxidized surface of Ti-6\%Al-4\%V alloy at $1123 \mathrm{~K}$ for $3.6 \mathrm{ks}$ in air, (a) SEM image, (b)composition image, characteristic X-ray images of (c) $\mathrm{AlK} \alpha$, (d) $\mathrm{TiK} \alpha$, (e) $\mathrm{VK} \alpha$ and (f) $\mathrm{OK} \alpha$.

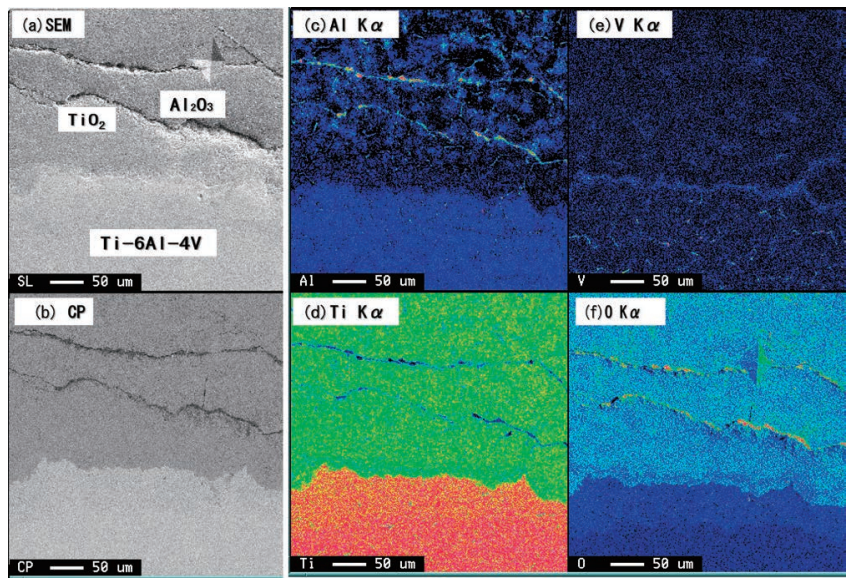

Fig. 5 Cross-sections of the oxidized surface of Ti-6\%Al$4 \% \mathrm{~V}$ alloy at $1273 \mathrm{~K}$ for $172.8 \mathrm{ks}$ in air, (a) SEM image, (b) composition image, characteristic X-ray images of (c) $\mathrm{AlK} \alpha$, (d) $\mathrm{TiK} \alpha$, (e) $\mathrm{VK} \alpha$ and (f) $\mathrm{OK} \alpha$.
$\mathrm{V}_{2} \mathrm{O}_{5}$ 中の Vのピークは観察されなかったが， $\mathrm{Ti}-4 \% \mathrm{~V}$ 合金の 場合 ${ }^{1)}$ と同様, $\mathrm{V}_{2} \mathrm{O}_{5}$ 中の $\mathrm{V}$ のピークよりもむしろ $\mathrm{V}_{2} \mathrm{O}_{3}$ に相 当する Vピークが, 微弱ではあるが観察される ${ }^{11)}$

3.1 .2 等速 (非等温) 酸化

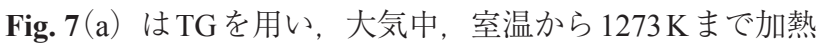
速度（2３0） K/minで加熱した場合の本合金の等速高温酸 化実験結果である。酸化増量は，加熱速度に大きく依存し， 加熱速度が遅いと酸化量は多い。しかしながら， $2 \mathrm{~K} / \mathrm{min}$ と $20 \mathrm{~K} / \mathrm{min}$ を比較すると， $1273 \mathrm{~K}$ の温度に達するには，10倍 の時間が経過しているにもかかわらず3倍程度の酸化量であ
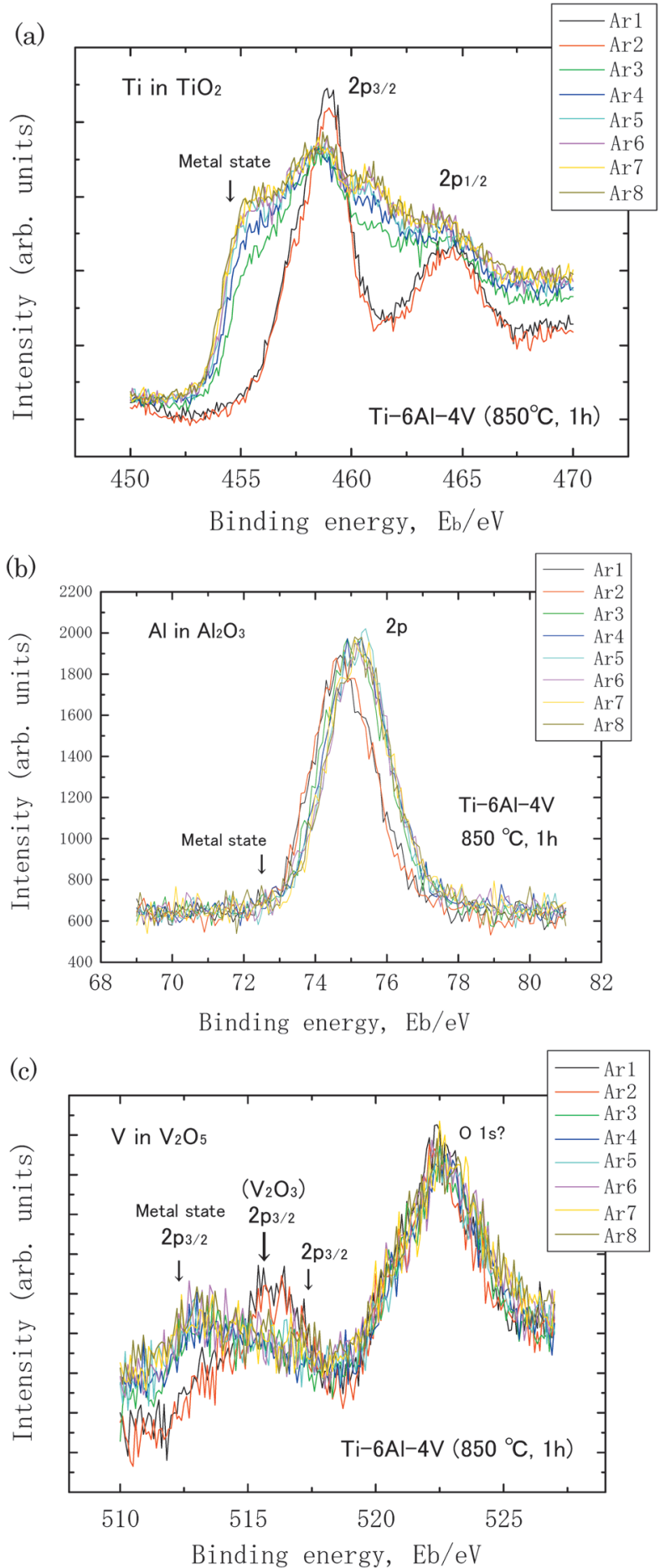

Fig. 6 Successive XPS spectra of (a) $\mathrm{Ti} 2 \mathrm{p}\left(\mathrm{Ti}\right.$ in $\left.\mathrm{TiO}_{2}\right)$, (b) $\mathrm{A} 12 \mathrm{p}\left(\mathrm{Al}\right.$ in $\left.\mathrm{Al}_{2} \mathrm{O}_{3}\right)$ and (c) $\mathrm{V} 2 \mathrm{p}\left(\mathrm{V}\right.$ in $\left.\mathrm{V}_{2} \mathrm{O}_{5}\right)$ taken from $\mathrm{Ti}-6 \% \mathrm{Al}-4 \% \mathrm{~V}$ alloy oxidized at $1123 \mathrm{~K}$ for $3.6 \mathrm{ks}$ in air. 


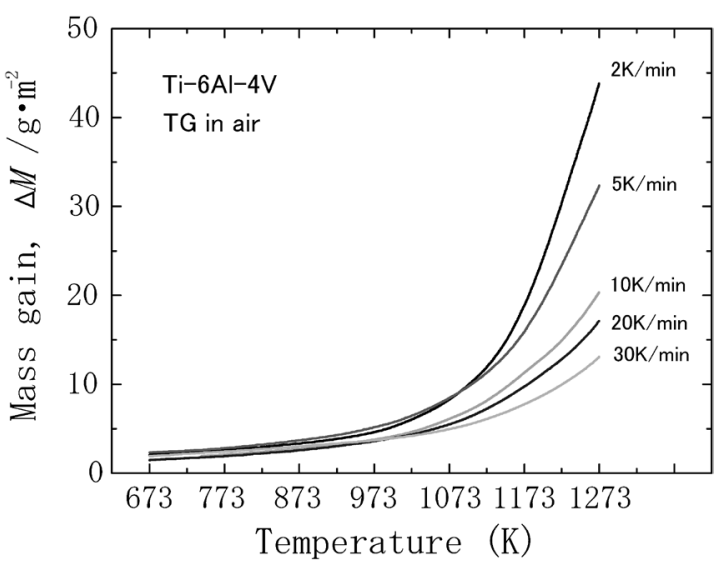

Fig. 7(a) TG curves at various heating rates of $\mathrm{Ti}-6 \% \mathrm{Al}-$ $4 \% \mathrm{~V}$ alloys in air.

(a) $2 \mathrm{~K} / \mathrm{min}$

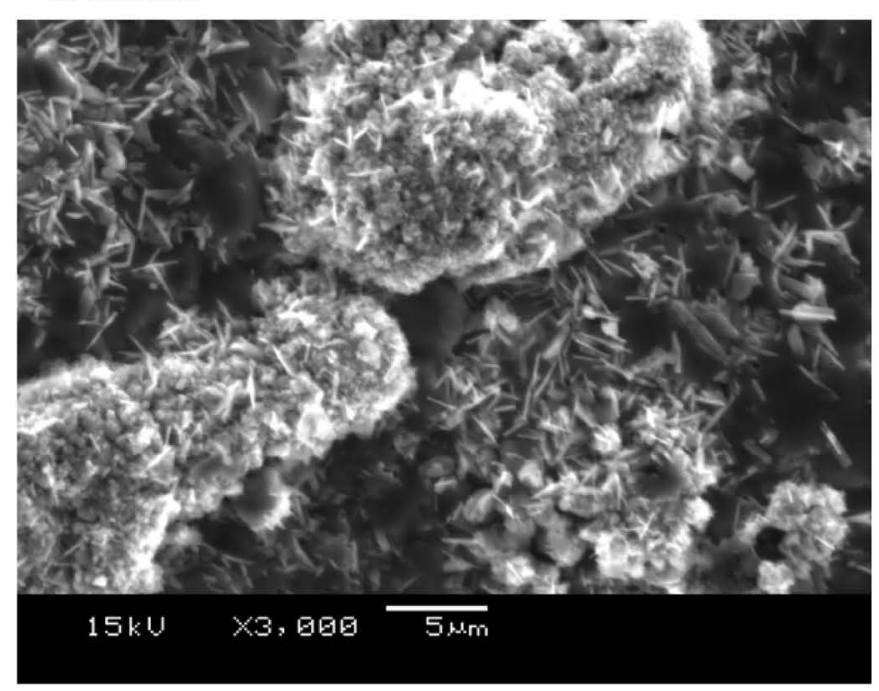

Fig. 8 SEM photographs of the oxidized surface of Ti-6\%Al-4\%V alloys after TG experiments at heating rates of (a) $2 \mathrm{~K} / \mathrm{min}$ and (b) $20 \mathrm{~K} / \mathrm{min}$ in air (R.T. $\sim 1273 \mathrm{~K})$.

る。これは, Fig. 1で時間の平方根と酸化量が関係していた ことから，時間の平方根で考えると 3 倍程度となり，大まか には時間の平方根，すなわち拡散律速が支配しているようで ある。

Fig. 7(b) は, Fig. 7(a) における加熱速度 $(2 \sim 30) \mathrm{K} / \mathrm{min}$ での酸化増量 $(\Delta M)$ を温度 $T$ で微分した $(\mathrm{d} \Delta M / \mathrm{d} T)-T$ 曲線 である。各加熱速度において加熱温度が $943 \mathrm{~K}$ 付近までは, $\mathrm{d} \Delta M / \mathrm{d} T$ がほぼ一定であるが，それ以上の温度においてはそ れらが増加している。すなわち, $943 \mathrm{~K}$ 付近で $\mathrm{V}_{2} \mathrm{O}_{5}$ の $\mathrm{s}$ (固体) $\rightarrow 1$ (液体) 反応の遷移温度が存在し, $\mathrm{V}_{2} \mathrm{O}_{5}$ の溶融が $\mathrm{TG}$ 曲 線データに影響を与えている。

Fig. 8 (a) および（b）は TG 実験（R.T. $1000^{\circ} \mathrm{C）}$ 後にお ける加熱速度（a） $2 \mathrm{~K} / \mathrm{min}$ および（b） $20 \mathrm{~K} / \mathrm{min}$ の場合の本 合金の表面酸化皮膜のSEM写真である。両者において微細 な針状の酸化物，また加熱速度の遅い（a）2K/minにおいて は針状の粗い酸化物と合体・成長した比較的大きい，平滑な 酸化物も観察される。Fig. 8(a) および（b）との表面酸化物 形状の違いは, 溶融温度範囲を短時間で通過したか, ゆっく り通過したかによると考えられる。

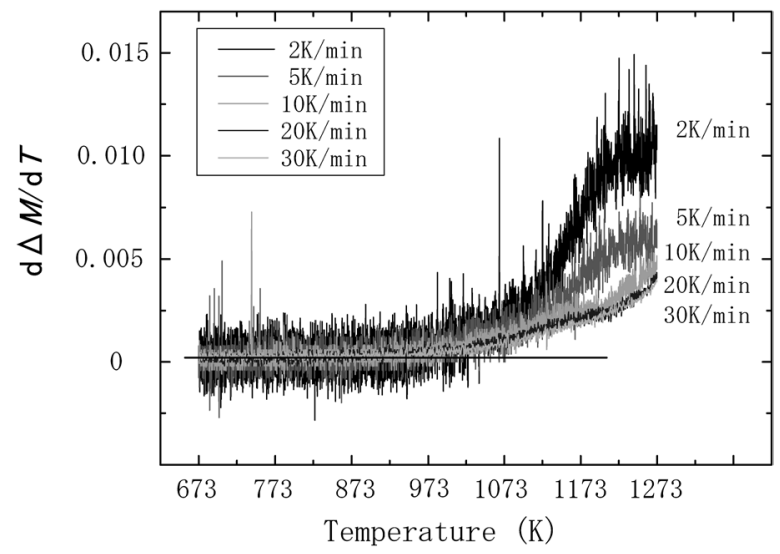

Fig. 7(b) $\mathrm{d} \Delta M / \mathrm{d} T-T$ curves at various heating rates of $\mathrm{Ti}-$ $6 \% \mathrm{Al}-4 \% \mathrm{~V}$ alloys in air.

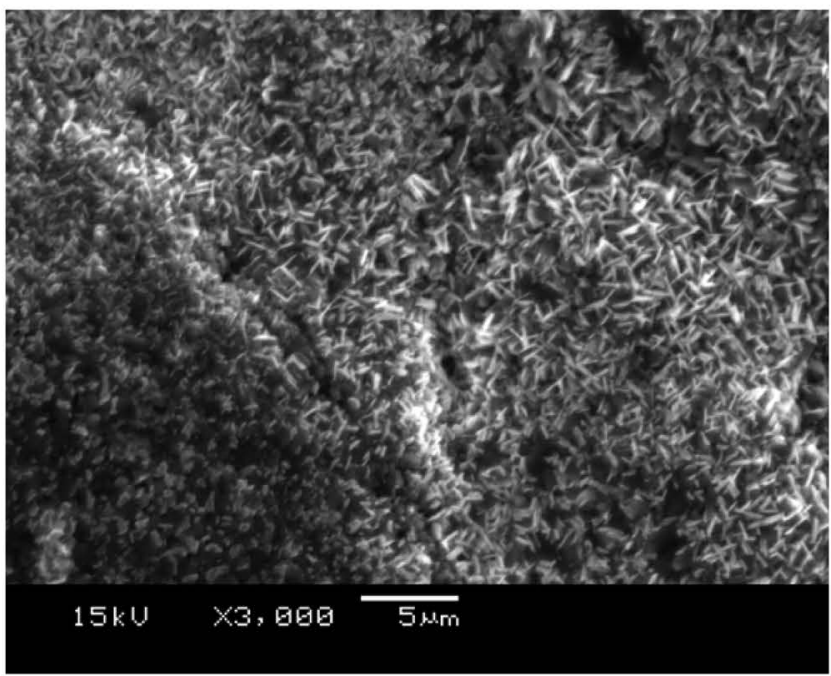


ここで， $B, R$ および $T$ は, それぞれ, 頻度因子, 気体定数, および絶刘温度である。

3.2 .2 等速加熱酸化実験による酸化量（TG実験による解 析, Ozawa 法 ${ }^{12)}$ の検討)

Ozawa 法とは TG 実験において加熱速度を変化させ, 各加 熱速度において，ある一定の“反応率”に達する温度を測 定・解析して反応の活性化エネルギーを求める方法である。 Ozawa 法は（a）単一素過程の場合 ${ }^{13)}$ に適用される信頼性の ある手法であるが，小澤はさらに並進反応，続発反応など の（b）複数素過程 $\left.{ }^{12)}, 14\right), 15 ）$ の場合についても報告している。

本系合金の高温酸化では，いくつかの化学反応が関与して おり, 今後さらに, 本研究において複数素過程（反応の条件 による場合分け）を考慮した等速酸化の速度論についても 検討すべきではあるが，ただ現段階では，本合金中におい て $670^{\circ} \mathrm{C}(943 \mathrm{~K})$ 付近で $\mathrm{V}_{2} \mathrm{O}_{5}$ が溶融・蒸発し, その後 $\mathrm{Al} の$ 酸化が進行し, 約 $820^{\circ} \mathrm{C}$ 以上（後述 Fig. 11 参照）では Ti の酸 化が優先的に起こると考え，本系合金の高温酸化反応が単一 素過程に極めて近いと仮定した。したがって，本研究では “反応率”を, “ある一定量に到達する酸化増量”と考えて Ozawa法を適用してみた。

いま，ある高温酸化反応において酸化物量（酸化増量）を $x$ とし，下に示す速度式に従い，アレニウスの法則が成り立 つとすれば

$$
\begin{gathered}
\frac{\mathrm{d} x}{\mathrm{~d} t^{\prime}}=k_{a} f(x) \\
k_{a}=A \exp \left(-\frac{Q_{a}}{R T}\right)
\end{gathered}
$$

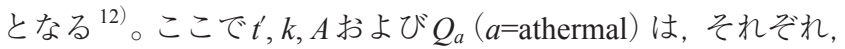
昇温開始後からの時間，反応速度定数，頻度因子，等速酸化 に対する見掛けの活性化エネルギーである。

TGにおいては，通常，定速昇温（降温）下で行うから， 定速 $\phi=\mathrm{d} T / \mathrm{d} t$ を式 (3) に代入して整理して $x=0$ から $x$ まで積分 すると

$$
\int_{0}^{x} \frac{\mathrm{d} x}{f(x)}=\frac{A}{\phi} \int_{0}^{T} \exp \left(-\frac{Q_{a}}{R T}\right) \mathrm{d} T
$$

式(5)の左辺を $F(x)$ とし, Doyleの $p$ 関数 ${ }^{16), 17)}$ を導入すれ ば

$$
F(x)=\frac{A Q_{a}}{\phi R} p\left(\frac{Q_{a}}{R T}\right)
$$

Fig. 7(a) のような TG 実験で昇温速度，2, 5, 10, 20, 30 K/min などの実験を行い，一定の変化率，たとえば一定の酸化率や 酸化増量においては, 左辺は一定值となる。左辺を $C$ とし, 対数をとると

$$
\log C=\log \frac{A Q_{a}}{\phi R}+\log p\left(\frac{Q_{a}}{R T}\right)
$$

Doyle の近似式 ${ }^{16), 17)}, \log p(y) \cong-2.315-0.4567 y$ を用い, 式(7) を整理すると以下のような Ozawa 法 ${ }^{12), 17), 18)}$ の式が 得られる。

$$
\log \phi=D-0.4567\left(\frac{Q_{a}}{R T}\right)
$$

ここで

$$
D=\left(\log \frac{A Q_{a}}{R}-\log C-2.315\right) .
$$

したがって, 各試料の TG 実験（酸化実験）において加熱速 度 $\phi$ を変化させ, ある一定の酸化増量における温度 $T$ を求め ることにより, 式(8) から等速酸化の活性化エネルギーが得 られる。

3.2.3 高温酸化の活性化エネルギー

Fig. 9 は高温域での $1173 \sim 1273 \mathrm{~K} て ゙ の$ 本合金の酸化増量 と時間 $(\sqrt{t})$ との関係であり, 酸化増量は時間のルート則 にのっている。Fig. 10 は等温酸化実験解析（式(2)）によ る本系合金の等温酸化の活性化エネルギー $Q_{i}$ を求めるため に $k_{m}^{2}$ の対数と酸化温度の逆数との関係を Ti-6\% $\mathrm{Al}$ 合金の結 果 ${ }^{1)}$ とともに示したものである。本系合金における等温酸 化の活性化エネルギーは $Q_{i}=223 \mathrm{~kJ} / \mathrm{mol}$ であり, Ti-6Al合金の $Q_{i}=253 \mathrm{~kJ} / \mathrm{mol}$ よりも小さいことがわかった。

Fig. 11 は, Ozawa法（式(8)） 12),17),18）による本合金の等

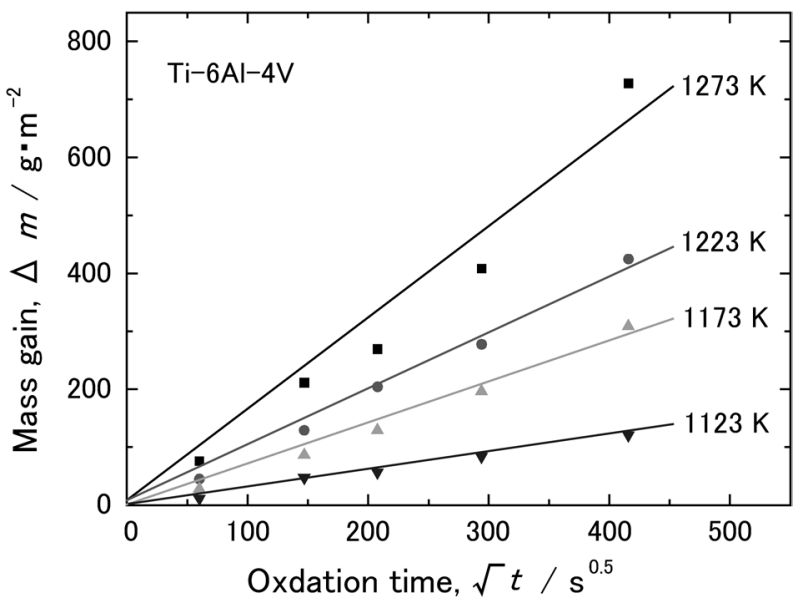

Fig. 9 Relation between mass gain and square root of oxidation time in $\mathrm{Ti}-6 \% \mathrm{Al}-4 \% \mathrm{~V}$ alloys at temperatures from 1173 to $1273 \mathrm{~K}$.

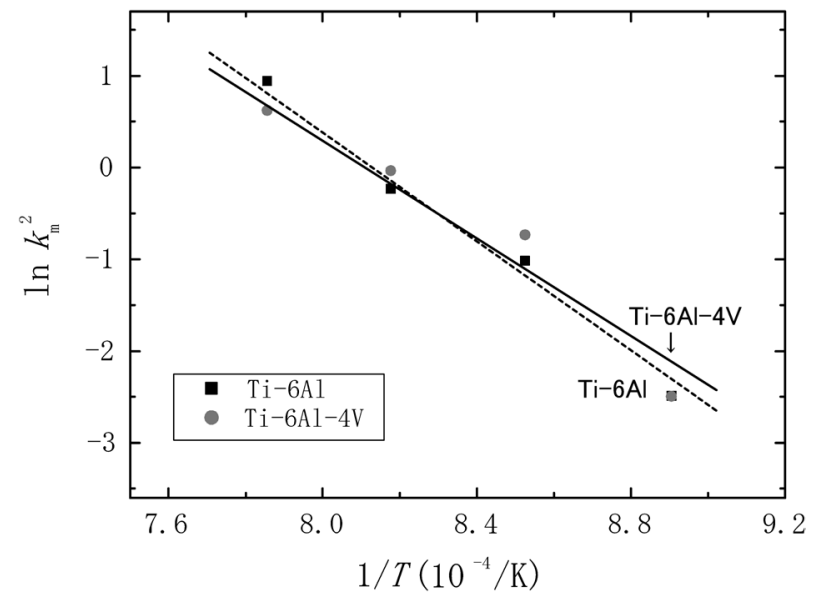

Fig. 10 Temperature dependence of $\ln k_{m}^{2}$ in $\mathrm{Ti}-6 \% \mathrm{Al}-4 \% \mathrm{~V}$ alloys. (isothermal oxidation experiments) 


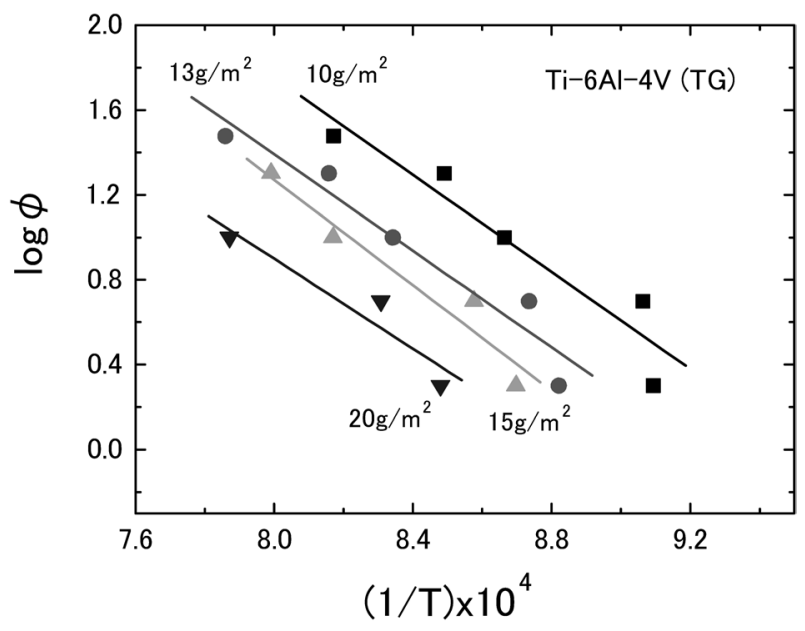

Fig. 11 Relation between $\log \phi$ and $1 / \mathrm{T}$ (TG experiments, heating rate $(2 \sim 30) \mathrm{K} / \mathrm{min})$.

速酸化での見掛けの酸化の活性化エネルギーを求めるため,

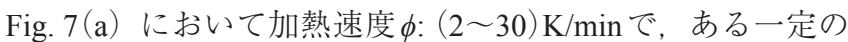
酸化増量 $\left(10,13,15,20 \mathrm{~g} / \mathrm{m}^{2}\right)$ に到達する温度を求めた $\log \phi$ と $1 / \mathrm{T}$ との関係である。Ozawa法による本合金の酸化の活性 化エネルギー, $Q_{a}=209 \mathrm{~kJ} / \mathrm{mol}$ を得た。この值は前述した本 合金の等温酸化の活性化エネルギー $\left(Q_{i}=223 \mathrm{~kJ} / \mathrm{mol}\right)$ よりも 少し小さいが, 近い值であった。

$\mathrm{Ti}(\beta)$ 中における $\mathrm{Al}, \mathrm{V}$ および $\mathrm{O}$ の拡散の活性化エネルギー $Q_{\mathrm{Al}}^{(\beta)}, Q_{\mathrm{V}}^{(\beta)}$ および $Q_{\mathrm{O}}^{(\beta)}$ は $Q_{\mathrm{Al}}^{(\beta)}=148 \mathrm{~kJ} / \mathrm{mol}^{19)}{ }^{(\beta)} Q_{\mathrm{V}}^{(\beta)}=168 \mathrm{~kJ} / \mathrm{mol}^{20)}$ お よび $Q_{\mathrm{O}}^{(\beta)}=246 \mathrm{~kJ} / \mathrm{mol}^{21)}$ ，また $\mathrm{TiO}_{2}$ 中の $(\mathrm{O}$ or Ti）の拡散の活 性化エネルギー $Q_{\mathrm{O}}^{\left(\mathrm{TiO}_{2}\right)}, Q_{\left.\mathrm{Ti}^{(} \mathrm{Ti}_{2}\right)}^{\left(\mathrm{T}^{2}\right.} \fallingdotseq 250 \mathrm{~kJ} / \mathrm{mol}^{22), 23)}$ である。本 研究の Ti-6Al-4V 合金における見掛けの酸化の活性化工ネ ルギーは $\mathrm{Ti}$ 中の $\mathrm{Al}, \mathrm{V}$ の拡散の活性化エネルギーよりも大き く, $\mathrm{Ti}$ あるいは $\mathrm{TiO}_{2}$ 中の $(\mathrm{O}$ or $\mathrm{Ti})$ の拡散の活性化エネル ギー值に近いことより, 酸化物中の拡散現象が重要な役割を 果たしていることがわかる。

\section{4. 結言}

Ti-6\%Al-4\%V 合金を 773〜973 K および1123〜1273 K の大 気中で酸化させ, 酸化皮膜と酸化機構についての調査および その速度論的考察を行い，以下のような結果を得た。

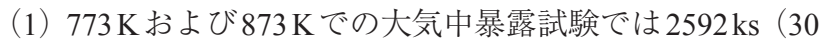
日）熱処理してもあまり酸化されないが，973Kでは時間と 共に顕著に酸化される。この高温酸化は $\mathrm{V}_{2} \mathrm{O}_{5}$ の生成・溶融
が関係している。

（2）本合金の表面酸化物の形状は，加熱温度 - 時間と共に, 微細な針状酸化物から粒状酸化物へと成長する。

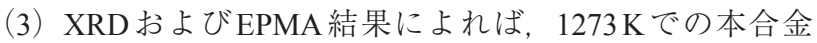
の断面・酸化物層は, 大部分, ルチル型 $\mathrm{TiO}_{2}$ 相であり， $\alpha$ アルミナ相は, 酸化表面ではなく酸化物相内部に帯状に存在 する。しかし，1123K Kでの本合金のXPS 結果によれば酸化物 の最表層には $\mathrm{TiO}_{2}$ 相だけでなく $\mathrm{Al}_{2} \mathrm{O}_{3}$ も存在する。

(4) 本合金における等温酸化における見掛けの酸化活性化 エネルギーは， $Q_{i}=223 \mathrm{~kJ} / \mathrm{mol}$ であり，等速酸化（Ozawa法） の活性化エネルギーは， $Q_{a}=209 \mathrm{~kJ} / \mathrm{mol}$ である。

\section{参 考 文 献}

1) T. Takahashi, Y. Minamino, H. Hirasawa and T. Ouchi: Mater. Trans., 55 (2015), 290-297.

2) 草道英武：鉄と鋼， 72 (1986), 538-546.

3) M. J. Donachie, Jr. : 岸 輝雄監修, 鈴木洋夫 - 原田健一郎訳, 内田老鶴圃, (1993)，1-85.

4) 井上道雄, 原 基, 中川時子, 品田 豊: 日本金属学会誌, 61 (1997), 511-518.

5) 原 基, 井上道雄, 中川時子：日本金属学会誌, 62（1998）, 691-700.

6) E. Sarathkumar and R. Krishnan: J. Mater. Sci., 18 (1983), 375-381.

7) 和泉 修: 非鉄材料, 日本金属学会, (1987), 118-142.

8) 池田勝彦, 小松伸也, 杉本隆史, 亀井 清: 軽金属, 44 (1994), 432-438.

9) 山脇道夫, 五十嵐孝雄, 米岡俊明, 菅野昌義：日本金属学会誌, $44(1980), 425-430$.

10）萬谷志郎編：金属物理化学, 日本金属学会, (1996), 81, 197210.

11）表面分析技術選書一 $X$ 線光電子分光法, 日本表面科学会編, 丸 善, (1998), 218.

12）小澤丈夫：日本金属学会会報，24（1985），797-804.

13）小澤丈夫：熱測定, 31 (2004), 125-132.

14) T. Ozawa: Polymer (London), 12 (1971), 150-158.

15）小澤丈夫：熱測定，31 (2004), 194-199.

16) C. D. Doyle: Nature, 207 (1965), 290-291.

17) 神戸博太郎, 小澤丈夫編 : 新版 熱分析, 講談社サイエンティ フィク, (1992), 57-86.

18）小澤丈夫, 吉田博久編：最新 熱分析, 講談社サイエンティ フィク, $(2005), 88-112$.

19）高橋知司, 松田信之, 久保周二, 日野孝紀, 小松正雄, 久幸晃 二：軽金属，54 (2004)，280-286.

20) 高橋知司, 南埜宜俊, 小松正雄：日本金属学会誌, 72 (2008), 1044-1051.

21) C. J. Rosa: Metall. Trans., 1 (1970), 2517-2522.

22) R. Haul and G. Dümbgen: J. Phys. Chem. Solids, 26 (1965), 1-10.

23) D. L. Venkatu and L. E. Poteat: Mater. Sci. Eng., 5 (1969/70), 258262. 